\title{
Evapotranspiration and Growth Response of Three Woody Ornamental Species Placed under Varying Irrigation Regimes
}

\author{
D.A. Devitt \\ Department of Range, Wildlife and Forestry, University of Nevada Reno, Reno, NV 89557 \\ R.L. Morris \\ Cooperative Extension, University of Nevada Reno, Las Vegas, NV 89104 \\ D.S. Neuman \\ Department of Biological Sciences, University of Nevada Las Vegas, Las Vegas, NV 89154
}

Additional index words. leaching fraction, tree size

\begin{abstract}
A 2-year study was conducted to quantify the actual evapotranspiration (ET $)$ of three woody ornamental trees placed under three different leaching fractions (LFs). Argentine mesquite (Prosopis alba Grisebach), desert willow [Chilopsis linearis (Cav.) Sweet var. linearis], and southern live oak (Quercus virginiana Mill.) (nursery seedling selection) were planted as 3.8-, 18.9-, or 56.8-liter container nursery stock outdoors in 190-liter plastic lysimeters in which weekly hydrologic balances were maintained. Weekly storage changes were measured with a portable hoist-load cell apparatus. Irrigations were applied to maintain LFs of $+0.25,0.00$, or -0.25 (theoretical) based on the equation irrigation $(\mathrm{I})=\mathbf{E T}$ I $(1$ - LF). Tree height, trunk diameter, canopy volume, leaf area index, total leaf area (oak only) and dry weight were monitored during the experiment or measured at final harvest. Average yearly ET was significantly influenced by planting size (oak and willow, $P \leq \mathbf{0 . 0 0 1})$ and leaching fraction imposed $(P \leq 0.001)$. Multiple regressions accounting for the variability in average yearly ET $_{\mathrm{a}}$ were comprised of different growth and water management variables depending on the species. LF, trunk diameter, and canopy volume accounted for $92 \%(P \leq 0.001)$ of the variability in the average yearly $\mathrm{ET}_{\mathrm{a}}$ of oak. Monthly ET ata were also evaluated, with multiple regressions based on data from nonwater-deficit trees, such that LF could be ignored. In the case of desert willow, monthly potential ET and trunk diameter accounted for $88 \%$ $(P \leq 0.001)$ of the variability in the monthly ET $\mathbf{T}_{\mathrm{a}}$. Results suggest that irrigators could apply water to arid urban landscapes more efficiently if irrigations were scheduled based on such information.
\end{abstract}

Population growth in the arid southwestern United States continues to place increasing pressure on available water resources. Water managers continue to look for ways to reduce water consumption in the industrial, agricultural, and urban sectors. Conventional agriculture has received a great deal of attention in terms of developing best management practices for improving on-farm water-use efficiency (Jensen 1973, 1975, Jensen et al., 1990). However, urban agriculture has not received the same amount of attention. Information on the water use of ornamental trees and other landscape plants (Martin et al., 1989; Vrecenak and Herrington, 1984; Welsh et al., 1991) is not nearly as extensive as that generated for agronomic crops. This disparity is particularly evident in the lack of long-term water-use estimates (yearly) for the nonagronomic species.

If maximum water savings are to be realized on urban landscapes, irrigation designers and managers need to differentiate the water needs of turfgrass from shrubs, ground cover, and trees. In addition, accurate estimates of the water use of landscape plants will provide the landscape architect or grounds manager with greater insight into the proper plant selection for a landscape to achieve a lower water requirement. However, even so-called lowwater-use landscaping is just as susceptible to poor irrigation management. Thus, this research was conducted to generate long-

Received for publication 15 Jan. 1993. Accepted for publication 19 July 1993. We thank the Las Vegas Valley Water District for financial support of this research project. We would also like to thank Jeff Andersen, Linda Vanden Heuvel, and Karen Dyka for their able laboratory and field assistance. The cost of publishing this paper was defrayed in part by the payment of page charges. Under postal regulations, this paper therefore must be hereby marked advertisement solely to indicate this fact. term water-use estimates for three woody ornamental species and to determine the growth, plant water status, and water use of these trees in response to different irrigation regimes.

\section{Materials and Methods}

Argentine mesquite, desert willow, and southern live oak (nursery seedling selection) were grown outdoors (in Las Vegas, Nev.) in nondraining 190-liter rigid plastic containers (lysimeters) with a diameter of $0.54 \mathrm{~m}$. Trees were planted as 3.8-, 18.9-, or 56.8-liter (container) nursery stock. Lysimeters were filled with a soil mix composed of $75 \%$ blow sand and $25 \%$ forest litter-bark mix. The lysimeters were lowered into open-ended concrete pipes that had a sand base flooring. The lysimeters were situated such that the soil level inside and outside of the lysimeters were the same. An air gap existed between the lysimeter and concrete pipe $(\approx 15 \mathrm{~cm})$, which was filled at the surface with a 31-cm-diameter roll of burlap-covered R19 insulation (wedged) to minimize the impact of ambient air temperatures on root temperatures. All trees were fertilized twice annually with a $15 \mathrm{~N}-6.5 \mathrm{P}-12.5 \mathrm{~K}$ granular fertilizer at a rate of $18.6 \mathrm{~g} / \mathrm{lysimeter}\left(0.2287 \mathrm{~m}^{2}\right.$ lysimeter surface area). Trees were also foliar sprayed (to runoff) once per year with an all purpose micronutrient fertilizer $(15 \mathrm{~N}-13 \mathrm{P}-12.5 \mathrm{~K}, 0.15 \%$ chelated $\mathrm{Fe}$ and $\mathrm{Mn}$ ) at a concentration of $0.9 \mathrm{~g} \cdot \mathrm{liter}^{-1}$. The area between lysimeters (4.9-m centers between trees with offset rows, five rows of 18 lysimeters per row) was planted to either tall fescue (Festuca arundinacea Schreb.) or common bermudagrass [Cynodon dactylon (L.) Pers.] to minimize the effects of bare soil on the energy balance of isolated trees and to simulate an urban landscape setting. The turfgrass was irrigated via subsurface drip irrigation to 
eliminate the possibility of surface water entering the lysimeters. In February 1990, after a 3-month establishment period, irrigation treatments were imposed for 2 years by placing the trees under leaching fractions (drainage volume/irrigation volume) of +0.25 , 0.00 , or -0.25 . These leaching fractions were maintained by applying irrigations twice weekly based on the equation $\mathrm{I}=\mathrm{ET} /(1$ $-\mathrm{LF})$, where I is the irrigation volume to apply, ET is the actual evapotranspiration, and LF is the leaching fraction. Thus, a deficit soil water status was attained by placing a theoretical negative LF $(-0.25)$ into the equation, resulting in each week's total irrigation for the $-0.25 \mathrm{LF}$ treatment to be less than the previous week's ET. ET was measured by using the hydrologic balance approach of $\mathrm{ET}_{\mathrm{a}}^{\mathrm{a}}=($ irrigation + precipitation $)$ - drainage - change in storage, where changes in soil water in storage were estimated as the difference in lysimeter weighings taken every 7 days with a 2270kg-capacity, 0.1\% accuracy load cell (Port-aweigh 4260; Measurements Systems Intl., Seattle, Wash.). To do this, nylon slings were wrapped around the lysimeters and connected to metal hooks that hung from a rectangular metal frame attached to the load cell. The load cell was attached to an electrical hoist that was mounted on a large movable frame that was positioned over each lysimeter. Drainage for each individual tree was collected 4 days per week by placing a vacuum of $17 \mathrm{kPa}$ for $1 \mathrm{~h}$ on two large ceramic extraction cups buried in $10 \mathrm{~cm}$ of diatomaceous earth at the bottom of each lysimeter. At the end of the first year, soil water in storage was reestablished to initial values in all lysimeters by applying additional water. The same protocol for irrigation treatments was then reimposed for a second year.

Trunk diameters (15 cm above soil line) and tree heights were measured at planting and monthly until harvest. Canopy volume was estimated by the upper-half spheroid method (Ludwig et al., 1975 ) at the end of the experiment. Leaf area index (LAI) was estimated for all trees at the end of the experiment with a plant canopy analyzer (model LAI-2000; LI-COR, Lincoln Neb.). LAI estimates using this technique were based on measuring radiation attenuation through the canopy. Leaf area was estimated with a leaf area meter (Delta T area meter; Delta T Devices, Cambridge, England). Total leaf area was estimated only for the oak trees by collecting leaves that had fallen and were removed from the trees at the end of the experiment. At the end of the experiment (February 1992), all trees were cut at the soil surface and immediately weighed on a large top-loading balance to the nearest gram. All leaves were removed from the oak trees before cutting, whereas mesquite and willow were without leaves at the time of cutting. Tree cuttings were allowed to dry for 5 months outdoors and then reweighed. Total above-ground dry weight (not including leaves) was estimated from oven-dried ( $70 \mathrm{C}$ for $48 \mathrm{~h}$ ) subsamples $(\approx 10 \%$ of total weight) taken at the end of the 5-month drying period.

Meteorological conditions were monitored with an automated weather station (model 012; Campbell Scientific, Logan Utah), which was situated in the center of the experimental area. Hourly measurements of solar radiation, maximum and minimum temperature, relative humidity, wind run, and rainfall were downloaded to a computer. Potential evapotranspiration (ETo $)$ was estimated with the Penman combination equation (Devitt et al., 1983).

The experiment was replicated $(n=3)$ in a randomized block design (species $\times$ planting container size $\times$ leaching fraction) and data were analyzed with descriptive statistics, analysis of variance (ANOVA), or linear and multiple linear regression analysis. Multiple regressions were performed in a backward stepwise manner, with deletion of terms occurring when $P$ values for the $t$ test exceeded 0.05 . Average treatment values were compared based on a least significant difference (LSD) generated from a mean square of the error term from the corresponding ANOVA.

\section{Results}

All growth characteristics measured on oak trees (height, trunk diameter, canopy volume, leaf area index, total leaf area, and dry weight) separated by planting size (Table $1, P \leq 0.01$ ). However, in mesquite and willow, only height, trunk diameter, and dry weight separated by planting size $(P \leq 0.001)$. Separation of growth characteristics by irrigation treatment (LF) occurred only for LAI in mesquite, and significant interactions of planting size and irrigation treatment on growth characteristics were observed only for the oak canopy volume data $(P \leq 0.05)$. Statistical analysis (ANOVA) of average yearly ET (Table 2 ) indicated significant separation by LF for all three species $(P \leq 0.001)$. This separation in $\mathrm{ET}_{\mathrm{a}}$ by LF treatments was clearest when comparisons were made between the -0.25 and the $+0.25 \mathrm{LF}$ treatments $\left(\mathrm{LSD}_{0.05}\right)$. ETa also separated by planting size in oak and willow $(P \leq 0.001)$. A significant interaction of size and LF on ET was observed only in oak $(P \leq 0.05)$. ET on a monthly basis for all three species is shown in Fig. 1 for the 56.8-liter planting container-sized trees, separated by the LF treatments imposed. The general shape of these curves followed the seasonal sinusoidal shape of the ET data, which was $212 \mathrm{~cm}$ in year 1 and $227 \mathrm{~cm}$ in year 2 .

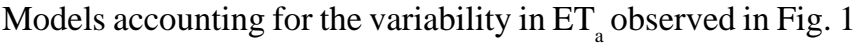
and Table 2 were developed for all three species based on significant relationships between ET and growth and size measurements and LF. There was a positive linear relationship between average yearly $\mathrm{ET}_{\mathrm{a}}$ and total dry matter at harvest, with separation of data based on LF ( oak, $-0.25 \mathrm{LF}, r=0.83^{* *}, 0.00$ and $+0.25 \mathrm{LF}, r=$ $0.97^{* * *}$; mesquite, $-0.25 \mathrm{LF}, r=0.82^{* *}, 0.00$ and $+0.25 \mathrm{LF}, r=$ $0.68^{* *}$; willow, $-0.25 \mathrm{LF}, r=0.79^{* *}, 0.00$ and $\left.+0.25 \mathrm{LF}, r=0.71^{* * *}\right)$. Linear relationships were also observed for all three species (data from all irrigation and planting size treatments) between trunk diameter and dry weight at harvest [oak dry weight $=-0.086+0.05$ (diameter), $r=0.93^{* * *}$; willow dry weight $=-0.52+0.04$ (diameter), $r=0.91^{* * *}$; mesquite dry weight $=-0.83+0.05$ (diameter), $r=0.92^{* * *}$. A similar separation of the ET data based on LF was also observed when trunk diameters were regressed against average yearly $\mathrm{ET}_{\text {a }}$ (Fig. 2). Other growth parameters such as tree height, canopy volume, and total leaf area were also cross correlated with ET ${ }_{\mathrm{a}}$ but are shown only for oak (Fig. 3). Tree height and total leaf area vs. ET for oak (Fig. 3) revealed a significant divergence based on irrigation treatments $(-0.25$ LF vs. 0.00 and $+0.25 \mathrm{LF}$ ). However, canopy volume vs. ET did not show this same degree of divergence in the data based on LF treatments. In fact, when the data were plotted to a single regression line, no decline in the correlation coefficient or level of significance ( $r=$ $0.92^{* * *}$ ) was observed.

Growth characteristics were combined with water parameters in multiple linear regression equations to determine which variables were the most suitable estimators of ET $_{a}$ (in accounting for the largest amount of variability in the average yearly ET $_{\mathrm{a}}$. A detailed analysis has shown that 1) for oak, LF can be combined with canopy volumes and trunk diameters to account for most of the variation $(92 \%)$ in average yearly $\mathrm{ET}_{\mathrm{a}}\left[\mathrm{ET}_{\mathrm{a}}=200.27+342.5\right.$ $(\mathrm{LF})+8.4$ (diameter) +446.3 (canopy), $\left.\left.r=0.96^{* * *}\right], 2\right)$ for mesquite, LF can be combined with LAI and height to account for $71 \%$ of the variability in average yearly $\mathrm{ET}_{\mathrm{a}}\left[\mathrm{ET}_{\mathrm{a}}=35.37+388.8\right.$ $(\mathrm{LF})+185.4$ (height) $\left.+382.9(\mathrm{LAI}), r=0.84^{\mathrm{a} * *}\right]$, and 3 ) for willow, LF can be combined with trunk diameters to account for $72 \%$ of the variability in the average yearly $\mathrm{ET}_{\mathrm{a}}\left[\mathrm{ET}_{\mathrm{a}}=285.85+364.20(\mathrm{LF})\right.$ 
Table 1. Size characteristics measured at harvest for oak, mesquite, and willow, separated by planting size and leaching fraction (LF) imposed over the 2-year experimental period $(n=3)$.

\begin{tabular}{|c|c|c|c|c|c|c|c|}
\hline $\begin{array}{l}\text { Planting } \\
\text { size }^{z}\end{array}$ & $\mathrm{LF}^{\mathrm{y}}$ & $\begin{array}{l}\mathrm{Ht} \\
(\mathrm{m})\end{array}$ & $\begin{array}{l}\text { Trunk } \\
\text { diam } \\
(\mathrm{mm})\end{array}$ & $\begin{array}{c}\text { Canopy } \\
\text { vol } \\
\left(\mathrm{m}^{3}\right)\end{array}$ & $\mathrm{LAI}^{\mathrm{x}}$ & $\begin{array}{c}\text { Dry } \\
\text { wt } \\
(\mathrm{kg})\end{array}$ & $\begin{array}{l}\text { Total } \\
\text { leaf } \\
\text { area } \\
\left(\mathrm{cm}^{2}\right)\end{array}$ \\
\hline \multicolumn{8}{|c|}{ Oak } \\
\hline \multirow[t]{3}{*}{3.8} & -0.25 & 1.09 & 18.69 & 0.15 & 0.69 & 0.31 & 5709 \\
\hline & 0.00 & 1.05 & 21.45 & 0.08 & 0.53 & 0.16 & 2490 \\
\hline & 0.25 & 1.15 & 18.94 & 0.06 & 0.50 & 0.17 & 2091 \\
\hline \multirow[t]{3}{*}{18.9} & -0.25 & 1.49 & 21.88 & 0.07 & 0.47 & 0.28 & 3855 \\
\hline & 0.00 & 1.48 & 21.92 & 0.15 & 0.53 & 0.24 & 3843 \\
\hline & 0.25 & 1.52 & 23.11 & 0.16 & 0.58 & 0.32 & 4240 \\
\hline \multirow[t]{3}{*}{56.8} & -0.25 & 2.11 & 34.63 & 0.35 & 0.63 & 0.91 & 8348 \\
\hline & 0.00 & 1.79 & 37.87 & 0.59 & 0.98 & 0.95 & 9188 \\
\hline & 0.25 & 2.22 & 43.29 & 0.91 & 1.03 & 1.59 & 10978 \\
\hline \multirow[t]{2}{*}{$\operatorname{LSD}_{(0.05)}$} & & 0.64 & 8.35 & 0.28 & 0.33 & 0.29 & 4129 \\
\hline & \multicolumn{7}{|c|}{ Mesquite } \\
\hline \multirow[t]{4}{*}{3.8} & -0.25 & 1.15 & 19.47 & 0.36 & 0.66 & 0.33 & --- \\
\hline & 0.00 & 1.22 & 28.51 & 0.68 & 1.39 & 0.67 & --- \\
\hline & 0.25 & 1.49 & 31.41 & 1.27 & 1.11 & 0.93 & --- \\
\hline & -0.25 & 1.70 & 32.12 & 0.70 & 0.76 & 0.60 & --- \\
\hline \multirow[t]{3}{*}{18.9} & 0.00 & 2.14 & 29.73 & 1.04 & 0.87 & 0.80 & --- \\
\hline & 0.25 & 2.08 & 34.20 & 1.41 & 0.98 & 0.95 & --- \\
\hline & -0.25 & 2.80 & 41.32 & 1.88 & 0.46 & 1.43 & --- \\
\hline \multirow[t]{2}{*}{56.8} & 0.00 & 2.38 & 38.92 & 1.86 & 0.84 & 1.37 & --- \\
\hline & 0.25 & 2.81 & 46.65 & 1.59 & 0.71 & 1.64 & --- \\
\hline \multirow[t]{2}{*}{$\operatorname{LSD}_{(0.05)}$} & & 0.64 & 9.46 & 1.59 & 0.55 & 0.25 & --- \\
\hline & \multicolumn{7}{|c|}{ Willow } \\
\hline \multirow[t]{3}{*}{3.8} & -0.25 & 1.26 & 19.77 & 0.19 & 0.60 & 0.19 & --- \\
\hline & 0.00 & 1.06 & 17.91 & 0.20 & 0.57 & 0.17 & --- \\
\hline & 0.25 & 1.26 & 20.98 & 0.16 & 0.51 & 0.21 & --- \\
\hline \multirow[t]{3}{*}{18.9} & -0.25 & 1.18 & 22.94 & 0.27 & 0.69 & 0.24 & --- \\
\hline & 0.00 & 1.38 & 20.43 & 0.39 & 0.53 & 0.27 & --- \\
\hline & 0.25 & 1.24 & 26.06 & 0.27 & 0.42 & 0.29 & --- \\
\hline \multirow[t]{3}{*}{56.8} & -0.25 & 1.87 & 31.77 & 0.36 & 0.45 & 0.62 & --- \\
\hline & 0.00 & 1.87 & 30.82 & 0.42 & 0.50 & 0.66 & --- \\
\hline & 0.25 & 1.55 & 31.88 & 0.20 & 0.48 & 0.50 & --- \\
\hline $\operatorname{LSD}_{(0.05)}$ & & 0.49 & 7.85 & 0.31 & 0.20 & 0.12 & --- \\
\hline
\end{tabular}

${ }^{\mathrm{z}}$ Nursery stock container size at planting.

${ }^{\mathrm{y}} \mathrm{A}$ theoretical negative LF was maintained by placing -0.25 into the equation $\mathrm{I}=\mathrm{ET}_{\mathrm{a}} /(1-\mathrm{LF})$.

${ }^{\mathrm{x}} \mathrm{LAI}=$ leaf area index measured with a plant canopy analyzer.

Table 2. Average yearly evapotranspiration (in liters) for oak, mesquite, and willow by planting size and leaching fraction (LF) treatment for the 2-year experimental period $(n=3)$.

\begin{tabular}{lrrrr}
\hline \hline $\begin{array}{l}\text { Planting } \\
\text { size }\end{array}$ & & \multicolumn{3}{c}{ Evapotranspiration (liters) } \\
\cline { 3 - 5 } (liter) & LF & Oak & Mesquite & Willow \\
\hline 3.8 & -0.25 & 386.7 & 447.6 & 366.6 \\
& 0.00 & 435.1 & 748.7 & 461.8 \\
& 0.25 & 442.2 & 781.3 & 540.4 \\
18.9 & -0.25 & 353.4 & 515.2 & 343.9 \\
& 0.00 & 401.8 & 838.3 & 475.9 \\
& 0.25 & 577.3 & 993.4 & 517.9 \\
56.8 & -0.25 & 504.1 & 570.1 & 435.7 \\
& 0.00 & 791.6 & 865.8 & 630.1 \\
& 0.25 & 1078.4 & 908.6 & 671.5 \\
LSD $_{(0.05)}$ & & 207.6 & 307.3 & 88.2 \\
\hline Nursyyy & & & &
\end{tabular}

${ }^{\mathrm{z}}$ Nursery stock container size at planting.
+8.41 (diameter), $\left.r=0.85^{* * *}\right]$. Multiple linear regressions were also conducted on monthly ET data, combining monthly ET, month of the year, and all growth characteristics (LF not considered). The analysis showed that 1) for oak, monthly ET can be combined with canopy volume to account for $79 \%$ of the variability in monthly $\mathrm{ET}_{\mathrm{a}}\left[\mathrm{ET}_{\mathrm{a}}=-35.31+3.63\left(\mathrm{ET}_{\mathrm{o}}\right)+62.64\right.$ (canopy), $\left.r=0.89^{* * *}\right], 2$ ) for mesquite, monthly $\mathrm{ET}_{\mathrm{o}}$ can be combined with the specific month of the year to account for $75 \%$ of the variability in monthly $\mathrm{ET}_{\mathrm{a}}\left[\mathrm{ET}_{\mathrm{a}}=-55.63+5.50\left(\mathrm{ET}_{\mathrm{o}}\right)+4.05\right.$ (month), $r=$ $0.87^{* * *}$ ], and 3) for willow, monthly $\mathrm{ET}_{\mathrm{o}}$ can be combined with trunk diameter to account for $88 \%$ of the variability in monthly $\mathrm{ETa}\left[\mathrm{ET}_{\mathrm{a}}=-50.34+3.73\left(\mathrm{ET}_{\mathrm{o}}\right)+1.13\right.$ (diameter), $\left.r=0.94^{* * * *}\right]$.

\section{Discussion}

This experiment has shown that ET is affected by planting size and LF. In apple, Stevenson (1989) found a similar result in which water use was linked to tree size and water availability, such that 


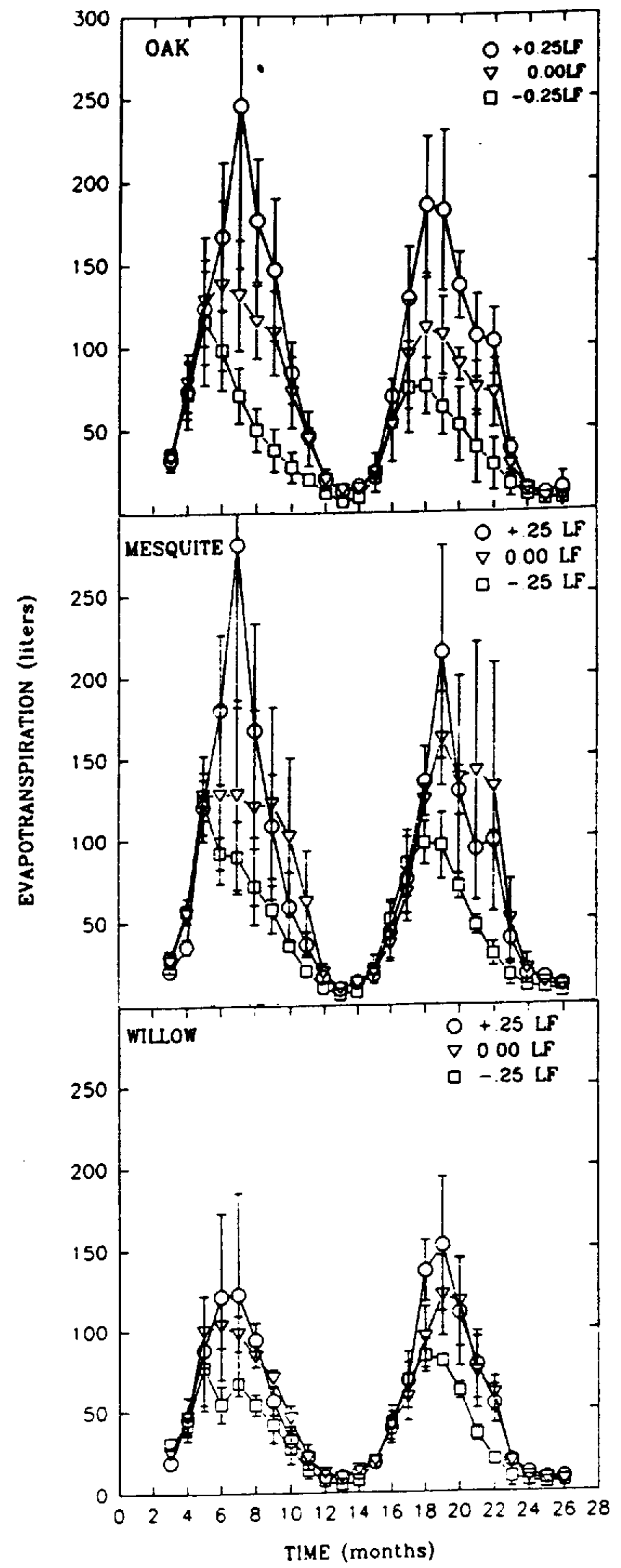

Fig. 1. Monthly evapotranspiration (liters) over a 2-year period for oak, mesquite, and willow. Data based on 56.8-liter planting container-size trees only, separated by leaching fraction treatments and plotted with SE bars.

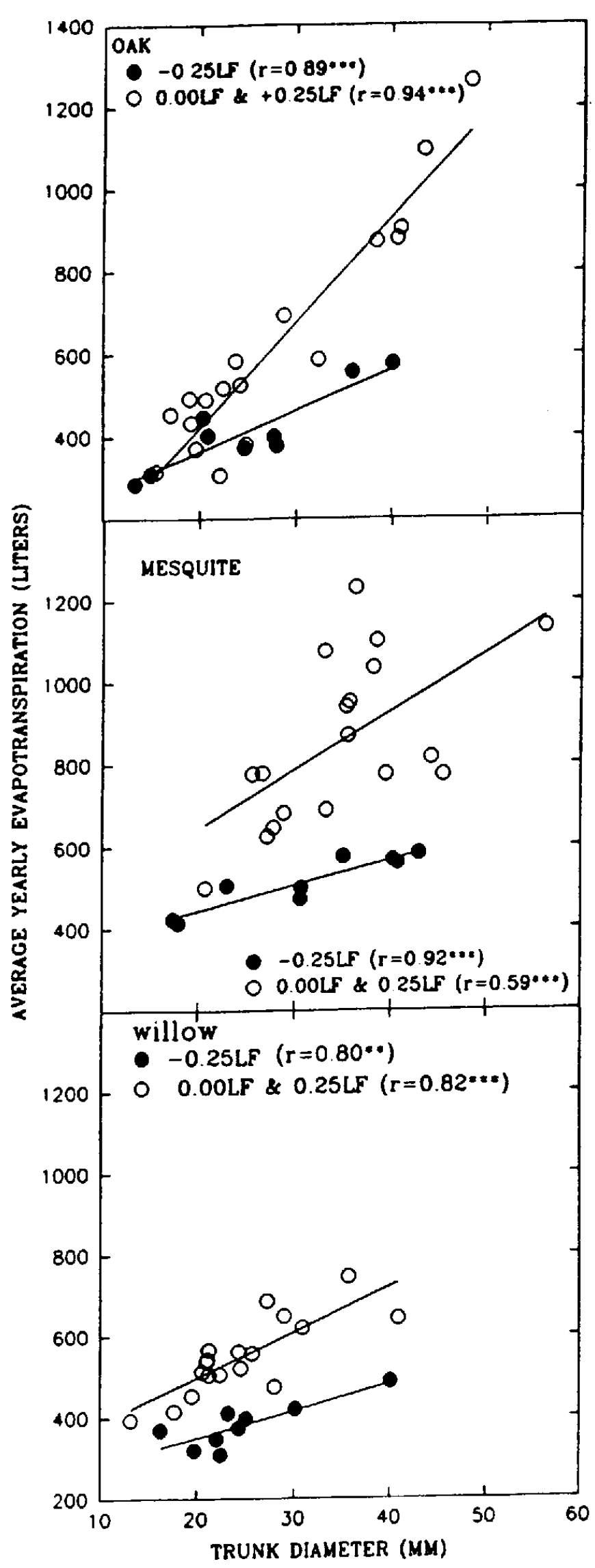

Fig. 2. Average yearly evapotranspiration (liters) as a function of trunk diameter $(\mathrm{mm})$ for oak, mesquite, and willow. Data separated based on leaching fractions of -0.25 vs. 0.00 and +0.25 . 


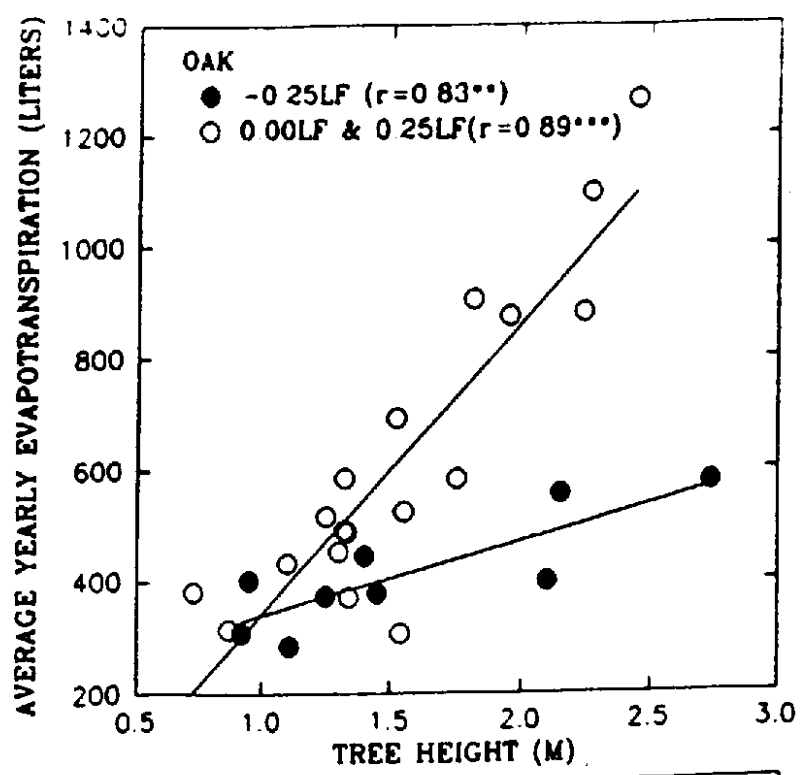

$\mathrm{ET}_{\mathrm{a}}$ increased as irrigation increased. Although size and LF influenced ET in oak and willow, there was no effect of planting size on mesquite. This was most likely due to growth habit. The 3.8-and 18.9-liter container-sized trees (shrub-like shape) had large flushes of spring growth compared to the 56.8-liter container sized-trees (tree-like shape with main trunk and supported canopy volume). Slower establishment of larger trees has been reported by Watson (1985). In the tree-like mesquite, no spring growth was allowed to occur on the trunk below the existing canopy. This difference in growth pattern between these planting sizes led to greater variability in the $\mathrm{ET}_{\mathrm{a}}$ data. For example, $\mathrm{ET}_{\mathrm{a}}$ values were found to be very similar for mesquite in the $+0.25 \mathrm{LF}$ treatment at the 18.9-liter planting size and at the 56.8-liter planting size. We found higher water-use rates in mesquite and oak as LF increased, as opposed to the more subtle change observed in willow (Fig. 1, Table 2). Ansley et al. (1992) has suggested that water use by mesquite increases with water availability. However, with willow, a smaller increase in $\mathrm{ET}_{\mathrm{a}}$ at the highest LF may have been due to sensitivity of willow to wetter soil conditions, as leaf chlorosis and leaf drop was observed in some trees.

When ET a was plotted as a function of dry weight or trunk diameter (Fig. 2), a clear separation in the data occurred based on LF groupings ( $-0.25 \mathrm{LF}$ vs. 0.00 and $+0.25 \mathrm{LF}$ treatments). This indicated reduced water use (at similar dry weights or trunk diameters) under water limited conditions (negative LF). Worthington et al. (1989) reported water use of peach trees to be relatively unaffected by availability of soil moisture until a threshold of $-1500 \mathrm{kPa}$ was reached (a value that would reflect waterdeficit conditions). In our study, the ET - dry weight relationship was used to estimate water-use efficiency from the 0.00 and +0.25 LF (nonwater-deficit) treatments. Our results indicated a higher water-use efficiency (lower $\mathrm{ET}_{\mathrm{a}}$ per unit dry weight) for mesquite (272.0) and willow (278.0) than for oak (448.4), a result that may explain why mesquite and willow are commonly found in hotter, drier habitats than oak. Higher water-use efficiency (photosynthesis to transpiration) was found by Field et al. (1983) for California evergreen species commonly found in drier habitats than for those evergreen species commonly found in wetter habitats. Interestingly, ET of oak was closely correlated with all growth parameters measured (tree height, trunk diameter, canopy volume) as opposed to a poorer response observed with willow and mesquite. No significant correlations were found between $\mathrm{ET}_{\mathrm{a}}$ and canopy

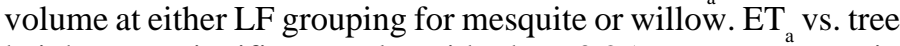
height was significant only with the -0.25 LF treatments in mesquite $\left(r=0.85^{* * *}\right)$ and willow $\left(r=0.81^{* *}\right)$. Rapid changes in tree height in mesquites and willow in spring altered relationships between tree height and planting size, which led to poorer tree height correlations. Canopy volume (half spheroidal method) correlated well with ET estimates for oak. However, we were unable to successfully use the half-spheroidal method for the more open canopies of willow and mesquite, which often had large flushes of spring growth. Rapid spring growth for mesquite, with slower growth rates during hot dry periods, has been previously reported (Sharifi et al., 1982). The nondivergence in the canopy volume vs. ET data, based on LF groupings for oak, was related to seasonal growth patterns. Oak trees showed little spring growth in the $-0.25 \mathrm{LF}$ treatments that would have altered their initial canopy volumes, whereas the canopy volume in the 0.00 and +0.25 LF treatment trees increased in a proportional fashion relative to $\mathrm{ET}_{\mathrm{a}}$. Thus, lack of separation in the canopy volume vs. ET $\mathrm{a}$ data based on LF groupings in oak was probably due to seasonal growth responses to the irrigation treatments. Results by Renquist (1987) suggest that water use per canopy area increased for smaller trees

Fig. 3. Average yearly evapotranspiration (liters) for oak as a function of (a) tree height $(\mathrm{m}),(\mathbf{b})$ canopy volume $\left(\mathrm{m}^{3}\right)$, and $(\mathbf{c})$ total leaf area $\left(\mathrm{cm}^{2}\right)$. Data separated based on leaching fractions of -0.25 vs. 0.00 and +0.25 . 
because of an oasis effect and because of an increased evaporation component. In our experiment, water use on a canopy volume basis or a trunk cross-sectional area basis also indicated higher wateruse rates for the smaller trees. Water use on a trunk cross-sectional area basis ranged from 0.20 to 0.41 liters $\cdot \mathrm{cm}^{-2} \cdot \mathrm{day}^{-1}$ for all three species, with higher values for the smaller trees. Chalmers et al. (1992) reported a similar range in $\mathrm{ET}_{\mathrm{a}}$ for Asian pears during late summer and early fall.

Long-term ET estimates are important when making water management decisions. However, they are not nearly as helpful to irrigators as monthly ET $\mathrm{a}_{\mathrm{a}}$ estimates. Models describing yearly ET in this experiment included LF as an important estimator. However, models that estimate ET based on knowledge of the LF infer a certain amount of knowledge of the existing water balance. Yearly estimates of LF are far more accurate than monthly estimates of LF because of the time required to reach steady state conditions with regards to water movement beyond the root zone (Devitt et al. 1991). Thus, models used to predict monthly ET should avoid including LF as an estimator. Monthly ET data (all three container-sized trees under nonwater-deficit conditions) were evaluated to determine the most suitable estimators to account for the monthly ET variability. Because only nonwaterdeficit trees were considered, this allowed elimination of the LF variable (Figs. 2 and 3). For oak and willow, monthly ET could be described by a combination of monthly $\mathrm{ET}_{\mathrm{o}}$ and a growth parameter. In mesquite, however, monthly ET $_{\mathrm{a}}$ estimates required no input of a growth parameter but only knowledge of the monthly ET and the month of the year. This would suggest that knowledge of the fundamental relationship between $\mathrm{ET}_{\mathrm{a}}$ and ET $\mathrm{E}_{\mathrm{o}}$ would hold over the range of tree sizes tested in this experiment (planting size and growth parameters eliminated in backward stepwise regression) and would further suggest that a crop coefficient (ET $\left./ \mathrm{ET}_{\mathrm{o}}\right)$ might have some validity for mesquite trees grown under the conditions of this experiment.

These results suggest that water use by woody ornamental trees can be a significant contribution to the total water use of a landscape in an arid environment. Multiple regressions developed between monthly and yearly ET and growth characteristics and water management variables in this experiment suggest that water requirements can be successfully estimated with such models. Accurate ET predictions for woody ornamentals would thus make it possible for irrigators to schedule more accurate irrigations on landscapes in arid environments. Although the trees in this experiment were relatively small and would represent plantings for an immature landscape, the increase in water use by planting size and LF treatment imposed suggests that, as these woody ornamentals mature, even greater amounts of water will be required relative to the total landscape water needs. The fact that these trees consumed greater amounts of water at the higher LFs would also indicate that plant selection alone will not necessarily lead to maximum water savings, but that water management must still play a critical role in developing low-water-use landscapes.

\section{Literature Cited}

Ansley, R.J., P.W. Jacoby, C.H. Meadors, and B.K. Lawerence. 1992. Soil and leaf water relations of differentially moisture-stressed honey mesquite (Prosopis glandulosa Torr). J. Arid Environ. 22:147-159.

Chalmers, D.J., P.K. Andrews, K.M. Harris, E.A. Cameron, and H.W. Caspari. 1992. Performance of drainage lysimeters for the evaluation of water use by Asian pears. J. Hort. Sci. 27:263-265.

Devitt, D.A., W.H. Jury, P. Sternberg, and L.H. Stolzy. 1983. Comparison of methods used to estimate evapotranspiration for leaching control. Irr. Sci. 4:59-69.

Devitt, D.A., D.C. Bowman, and R.L. Morris. 1991. Effects of irrigation frequency, salinity of irrigation water, and soil type on growth and response of bermudagrass. Arid Soil Res. Rehabilitation 5:35-46.

Field, C.J. Merino, and H.A. Mooney. 1983. Compromises between water-use efficiency and nitrogen-use efficiency in five species of California evergreens. Oceologia 60:384-389.

Jensen, M.E. 1973. Consumptive use of water and irrigation water requirements. Amer. Soc. Civil. Eng., New York.

Jensen, M.E. 1975. Scientific irrigation scheduling for salinity control of irrigation return flows. U.S. Govt. Printing Office, Washington, D.C. EPA Rpt. 600-2-75-064:1-92.

Jensen, M.E., R.D. Burman, and R.G. Allen. 1990. Evapotranspiration and irrigation water requirements. Amer. Soc. Civil Eng., New York.

Ludwig, J.A., J.F. Reynolds, and P.D. Whitson. 1975. Size-biomass relationships of several Chihuahuan desert shrubs. Amer. Midland Natl. 94:451-461.

Martin, C.A., H.G. Ponder, and C.H. Gilliam. 1989. Effects of irrigation rate and media on growth of Acer rubrum L. in large containers. J. Environ. Hort. 7:38-40.

Renquist, R. 1987. Evapotranspiration calculations for young peach trees and growth responses to irrigation amount and frequency. J. Hort. Sci. 22:221-223.

Sharifi, M.R., E.T. Nilsen, and P.W. Rundell. 1982. Biomass and net primary production of Prosopis glandulosa (Fabaceae) in the Sonoran desert of California. Amer. J. Bot. 69:760-767.

Stevenson, D.S. 1989. Irrigation subsurface return flows and water use in lysimeters containing apple trees. Can. J. Soil Sci. 69:769-778.

Vrecenak, A.J. and L.P. Herrington. 1984. Estimation of water use of landscape trees. J. Arbor. 10:313-319.

Watson, G.W. 1985. Tree size affects root regeneration and top growth. J. Abor. 11:37-40.

Welsh, D.F., J.M. Zajicek, and C.G. Lyons, Jr. 1991. Effect of seasons and irrigation regimes on plant growth and water-use of container-grown Photinia $\times$ fraseri. J. Environ. Hort. 9:79-82.

Worthington, J.W., J. Lasswell, and M.J. McFarland. 1989. Soil moisture and water use in lysimeter-grown peach trees. J. Hort. Sci. 24:440-443. 